\title{
IMPLEMENTASI INQUIRY TEACHING DALAM PELAJARAN MATEMATIKA
}

\author{
Buaddin Hasan \\ STKIP PGRI Bangkalan \\ E-mail: buaddinhasan@ stkippgri-bkl.ac.id
}

\begin{abstract}
ABSTRAK
Penelitian ini bertujuan untuk mengetahui kemampuan mengajukan pertanyaan, kemampuan berkerjasama dalam pelajaran matematika dengan menggunakan metode inquiry teaching dengan pendekatan strategi kooperatif. Penelitian kualitatif ini menggunakan studi deskriptif action research yang dilakukan dalam 2 siklus. Hasil penelitian ini menyatakan bahwa metode inquiry dapat merangsang pertanyaan, memberikan konsep dan prinsip penyelesaian yang terkait dengan masalah yang dihadapi siswa. sehingga metode inquiry menjadikan siswa lebih aktif dan kreatif serta mampu berpikir kritis dalam interaksi siswa maupun dalam menyelesaikan masalah dengan menggunakan kemampuannya secara mandiri.
\end{abstract}

Keyword : inquiry teaching, kemampuan bertanya, belajar aktif

Pembelajaran merupakan proses yang tidak hanya memindahkan pengetahuan dari guru pada siswa, melainkan suatu aktivitas yang memungkinkan siswa dapat membangun pengetahuannya sendiri dan melibatkan berbagai kegiatan serta tindakan yang harus dilakukan untuk mendapatkan hasil belajar yang lebih baik. Pembelajaran yang kondusif penuh interaksi timbal balik antara siswa dengan siswa, siswa dengan guru sangat didambakan oleh setiap pihak pada lingkup pendidikan terlebih jika menyangkut mutu sumber daya manusia. Salah satu cara pengembangan kegiatan pembelajaran yang menekankan berbagai kegiatan dan tindakan yaitu penerapan strategi pembelajaran yang sesuai dengan karakter siswa. Strategi pembelajaran merupakan cara yang teratur untuk mencapai tujuan pengajaran dan untuk memperoleh kemampuan dalam mengembangkan aktivitas belajar yang dilakukan guru dan siswa. 
Tall, dkk (2002) menyatakan bahwa tujuan pembelajaran matematika adalah untuk kesuksesan siswa. Kesuksesan tersebut diartikan sebagai keberhasilan siswa dalam memahami pelajaran. Namun, pada kenyataannya proses pembelajaran di sekolah masih berpusat pada guru (teacher centered). Morgan (2004) menyatakan bahwa pembelajaran yang berpusat pada guru hanya menjadikan siswa menirukan perlakuan yang diberikan guru (imitation). Hal itu menjadikan siswa kurang aktif dalam belajar. Siswa merasa cepat bosan saat mengikuti pelajaran sehingga berdampak pada kesuksesan siswa dalam memahami pelajaran dan penyelesaian masalah. Baxter, dkk (2010) menyatakan bahwa guru yang mendominasi percakapan dan iteraksi di dalam kelas, penjelasan materi yang hanya mengacu pada ketuntasan kurikulum menjadikan siswa mengalami kesulitan pada saat menyelesaikan masalah matematika.

Salah satu faktor penting dalam menunjang keberhasilan proses belajar mengajar adalah keaktifan belajar siswa. Sikap aktif terwujud dengan menempatkan siswa sebagai subyek pendidikan atau pembelajaran yang berpusat pada siswa (student centered), sedangkan peran guru adalah sebagai fasilitator dan bukan sumber utama pembelajaran (teacher centered). Siswa yang aktif mampu memanfaatkan ilmu yang diperoleh dalam kehidupan sehari-hari, dan mampu mengaplikasikan dalam pelajaran (constectual teaching).

Pembelajaran dengan strategi yang tepat hendaknya dilaksanakan pada setiap jenjang pendidikan serta dalam semua mata pelajaran termasuk matematika. Matematika merupakan salah satu ilmu dasar yang mempunyai peranan penting dalam upaya penguasaan ilmu pengetahuan dan teknologi. Matematika juga ilmu yang bertujuan untuk mendidik manusia agar dapat berfikir secara logis, kritis, rasional dan percaya diri. Menurut Hannula, Maijala \& Pehkonen (2004) kepecayaan siswa pada matematika dan pada diri mereka sebagai siswa yang belajar matematika akan memberikan peranan penting dalam pembelajaran dan kesuksesan mereka dalam matematika. Pengertian matematika yang telah disebutkan di atas memerlukan siswa untuk berpikir rasional, realistis dan objektif yang kesemuanya adalah beberapa indikator dari kepercayaan diri. Pemahaman, penguasaan materi serta prestasi belajar 
siswa merupakan indikator keberhasilan proses kegiatan pembelajaran matematika. Semakin tinggi pemahaman dan penguasaaan materi serta prestasi belajar maka semakin tinggi pula tingkat keberhasilan pembelajaran. Namun dalam kenyataannya, prestasi belajar matematika yang dicapai siswa masih rendah.

Menurut Chambers (2008) matematika adalah fakta-fakta objektif, sebuah studi tentang alasan dan logika, sebuah sistem di sekitar kita yang murni dan cantik, bebas dari pengaruh sosial, berdiri sendiri, dan mempunyai struktur yang saling berhubungan. Rendahnya prestasi belajar matematika juga disebabkan karena keaktifan dalam pembelajaran masih sangat rendah. Keaktifan siswa dalam pembelajaran matematika belum nampak terutama keaktifan dalam mengerjakan soal-soal latihan yang masih sangat kurang, begitu juga masih banyaknya siswa yang jarang mengajukan pertanyaan walaupun guru sering meminta siswa bertanya jika ada hal yang kurang paham serta keberanian siswa untuk aktif mengerjakan soal di depan kelas juga masih belum nampak. Kemampuan berfikir akan mempengaruhi keberhasilan hidup karena menyangkut apa yang akan dikerjakan dan apa yang akan dihasilkan individu. Menurut Bell ( 2011) pembelajaran matematika berbantuan komputer sangat efektif dan menyenangkan. Proses pembelajaran tidak lagi berpusat pada guru, melainkan siswa lebih aktif dalam proses pembelajaran. Hal ini yang menjadi tolak ukur bahwa pentingnya pemilihan metode dalam pembelajaran.

Inkuiri adalah salah satu strategi pembelajaran yang dikembangkan dalam dunia pendidikan. Melalui strategi ini, anak akan mengembangkan kreatifitas diri sendiri dengan bantuan yang diberikan oleh guru. Pengembangan kreatifitas anak dipentingkan dalam proses pendidikan mengingat anak secara potensial mempunyai kemampuan untuk berkreatifitas. Kreatifitas itu sendiri adalah modal dalam pencerdasan dan pendewasaaan anak. Melalui pendidikan proses pencerdasan, pendewasaan sosial dan emosional termasuk pendewasaan religius dibangun secara terarah. Pembelajaran inkuiri berarti suatu rangkaian kegiatan belajar yang melibatkan secara maksimal seluruh kemampuan siswa untuk mencari dan menyelidiki secara sistematis, kritis, logis, analitis, sehingga mereka dapat merumuskan sendiri penemuannya dengan penuh percaya diri (W. Gulo, 2008). 
Bilgin (2009) menyatakan bahwa siswa dengan kelompok inkuiri terbimbing yang belajar secara kooperatif mempunyai pemahaman yang lebih baik terhadap penguasaan konsep materi pelajaran dan menunjukkan sikap yang positif. Menurut Kubicek (2005), pembelajaran berbasis inkuiri dapat meningkatkan pemahaman siswa dengan melibatkan siswa dalam proses kegiatan pembelajaran secara aktif, sehingga konsep yang dicapai lebih baik. Swarso (Tim Dosen, 2000:128), menyatakan bahwa metode pembelajaran inkuiri mampu membangkitkan siswa untuk berperan secara aktif dalam proses pembelajaran, berpikir secara kreatif, dan mampu memecahkan masalah yang diberikan oleh gurunya.

Metode pembelajaran inkuiri tidak hanya mengembangkan kemampuan intelektual tetapi seluruh potensi yang ada, termasuk pengembangan emosional dan pengembangan keterampilan. Discovry learning, inqiury-based learning dan problem-based learning semuanya menggambarkan pengalaman siswa saat bergulat dengan pertanyaan atau masalah, berpartisipasi dalam langkah-langkah menyelesaikan masalah dan mengkomunikasikan apa yang mereka temukan kepada orang lain (Dell'Olio \& Tony Donk, 2007: 320). Di dalam metode pembelajaran inkuiri siswa dihadapkan pada sebuah masalah yang dibuat oleh guru, sehingga siswa harus berusaha secara aktif dengan kemampuan dan keterampilannya untuk mendapatkan menghasilkan penyelesaian dari masalah yang dihadapinya. Dengan metode pembelajaran inkuiri akan melatih siswa berani mengemukakan pendapat dan menemukan sendiri pengetahuannya yang berguna untuk memecahkan masalah yang dihadapinya.

Tujuan penelitian implementasi inquiry teaching dalam pelajaran matematika adalah: pertama untuk mengetahui peningkatkan kemampuan berpikir siswa secara mandiri, kemampuan menganalisa, kemampuan berpendapat, kemampuan bekerjasama dalam pelajaran matematika. Kedua mengetahui peningkatkan kualitas pembelajaran guru dalam pelajaran matematika. 


\section{Metode Penelitian}

Penelitian ini menggunakan pendekatan kualitatif dan studi deskriptif untuk implementasi strategi pembelajaran inkuiri dalam pelajaran matematika. Jenis penelitian yang digunakan adalah action research. Menurut Creswell (2009), salah satu karakteristik penelitian kualitatif adalah peneliti sebagai instrumen utama. Penelitian dilakukan dengan mengamati tindakan siswa dalam proses pembelajaran di kelas untuk mengetahui peningkatkan kemampuan berpikir siswa secara mandiri, kemampuan menganalisa, kemampuan berpendapat, kemampuan bekerjasama dalam pelajaran matematika.

Penelitian ini dilaksanakan di SMA Negeri 1 Grati, Pasuruan dengan mengambil data di kelas X MIA -1. Tahapan pengumpulan data yaitu observasi dilakukan bersamaan dengan implementasi tindakan. Proses observasi menggunakan lembar observasi yang meliputi lembar keterlaksanaan pembelajaran inkuiri oleh dua orang observer dan lembar kerja yang berisi soal matematika sebagai masalah dalam diskusi kelompok untuk dselesaikan oleh siswa secara mandiri. Untuk mengetahui kemampuan siswa secara individu guru memberikan tes. Soal tes diberikan setelah $\mathrm{p}$ tindakan penerapan strategi pembelajaran inkuiri pada tiap akhir pokok bahasan. Tes tersebut berupa soal esai. Analisis data yang digunakan dalam penelitian ini yaitu analisis kualitatif yang terdiri dari tiga komponen yaitu mereduksi data, penyajian data, dan penarikan kesimpulan.

\section{Hasil dan Pembahasan}

Strategi pembelajaran Inkuiri adalah model pembelajaran dimana siswa menemukan dan menggunakan berbagai macam sumber-sumber informasi dan ideide untuk menambah pemahaman mereka tentang suatu masalah, topik atau isu (Kuhlthau, Maniotes \& Caspari, 2007: 2). Pembelajaran ini yang menekankan pada proses berfikir secara kritis dan analitis untuk mencari dan menemukan sendiri jawaban dari suatu masalah yang dipertanyakan. Proses berfikir itu sendiri biasanya dilakukan melalui tanya jawa antara guru dan siswa. Dengan kata lain, inkuiri adalah suatu proses untuk memperoleh dan mendapatkan informasi dengan melakukan 
observasi dan atau eksperimen untuk mencari jawaban atau memecahkan masalah terhadap pertanyaan atau rumusan masalah dengan menggunakan kemampuan berpikir kritis dan logis.

Metode Inquiry melibatkan peserta didik secara aktif dalam pembelajaran yang kolaboratif dan keterampilan sosial, dan meminta kerjasama siswa dari hasil yang dicapai dalam proses pembelajaran sedangkan guru membantu siswa memahami asumsi apapun yang dikemukakan. Bell at al (2005) menyatakan ada empat tahap dalam pembelajaran inquiry, yaitu: confirmation inquiry, structured inquiry, guided inquiry, open inquiry. Empat tahapan tersebut menjadikan siswa terlibat aktif dalam proses pembelajaran. Metode inkuiri juga merupakan metode pembelajaran yang dalam penyampaian bahan pelajarannya tidak dalam bentuknya yang final, atau dalam artian tidak langsung. Artinya, dalam penyampaian metode inkuiri peserta didik sendirilah yang diberi peluang untuk mencari (menyelidiki/meneliti) dan memecahkan sendiri jawaban (permasalahan) dengan mempergunakan teknik pemecahan masalah. Namun demikian pengajar bertindak sebagai pengarah, mediator, dan fasilitator, yang wajib memberikan informasi yang relevan, sesuai dengan permasalahan atau materi pelajaran. Hal tersebut dapat berlangsung dalam kelompok-kelompok kecil dalam kelas melalui diskusi dan bermain peran. Dalam kegiatan ini peserta didik dituntut aktif terlibat dalam situasi belajar. Peserta didik menyadari masalah, mengajukan pertanyaan, selanjutnya menghimpun informasi sebelum mengambil keputusan (Munandar, 1995: 85). Dengan demikian sangat jelas metode inkuiri memberikan kebebasan yang besar pada peserta didik untuk mengembangkan dirinya, meskipun tidak terlepas dari peranan guru dalam memimpin, membimbing, dan memberi arahan dalam proses pembelajaran.

Ju-Ling Shih, dkk. (2010) mengatakan "Inquiry Based Learning is a concept which encourages teachers to allow earners to get in touch with authentic situations, and to explore and to solve problems that are analogs to real life" yang artinya pembelajaran inkuiri adalah suatu konsep yang mendorong guru untuk memberikan kesempatan pebelajar untuk memperoleh ketrampilan dengan 
menyajikan situasi nyata, dan untuk menyelidiki dan menyelesaikan masalah yang berkaitan dengan kehidupan nyata.

"Students will develop the skills required for scientific and technological inquiry, for solving problems, for communicating scientific ideas and results, for working collaboratively and for making informed decisions. The skills that students need to develop are: Initiating and Planning, Performing and Recording, Analyzing and Interpreting, and Communication and Teamwork" (Alberta Learning, 2003c, 2003d, p. 3).

Pada dasarnya siswa mampu mengembangkan kemampuan berpikir, dan juga dengan strategi penemuan untuk menyelesaikan masalah, mengkomunikasikan ide dan hasil temuan, bekerja secara kolaboratif dan membuat kesimpulan. Kemampuan siswa tersebut memerlukan suatu perencanaan pembelajaran yang baik, dalam hal ini strategi pembelajaran inkuiri menjadi alternatif dalam mengeksplorasi kemampuan siswa.

Menurut Khan (2012) pengajaran berbasis penyelidikan (inquiry) di kelas matematika memberikan kesempatan siswa untuk belajar lebih aktif dalam ruang kelas, meningkatkan interaksi sosial dan pengembangan intelektual dalam proses pembelajaran. Sebagai strategi pembelajaran, inkuiri dapat diimplementasikan secara terpadu dengan strategi lain sehingga dapat membantu pengembangan pengetahuan dan pemahaman serta kemampuan melakukan kegiatan inkuiri oleh siswa. Strategi pembelajaran inkuiri dapat digunakan untuk meningkatkan proses pembelajaran siswa, dan dapat disesuaikan dengan tujuan yang ingin dicapai oleh pembelajaran pada berbagai mata pelajaran, khususnya matematika, yaitu meliputi aspek: kemampuan mengemukakan pendapat, kemampuan menganalisa masalah, kemampuan menuliskan pendapatnya setelah melakukan pengamatan, dan kemampuan menyimpulkan.

Catatan hasil observasi selama proses pembelajaran dari observer membantu peneliti untuk refleksi, sehingga kualitas semakin meningkat. Hal ini sesuai dengan pernyataan Widhiartha (2008) observer mengamati kegiatan pembelajaran yang dilakukan dengan memfokuskan pada kinerja siswa sehingga permasalahan yang terjadi di kelas dapat dianalisis dan dicarikan solusi yang tepat, dengan demikian 
masalah yang terjadi di kelas pada saat kegiatan pembelajaran dapat dipecahkan secara bersama-sama dan kegiatan belajar selanjutnya dapat berjalan dengan baik dan meningkatkan kualitas pembelajaran.

Hasil observasi pada pelaksanaan pembelajaran siklus 1 sebagai berikut,

Tabel 3.1. Pengamatan Aktivitas Siswa

\begin{tabular}{|c|c|c|}
\hline Aspek & P1 & P2 \\
\hline $\begin{array}{l}\text { Bagaimana respon } \\
\text { kesiapan belajar siswa? }\end{array}$ & $\begin{array}{l}\text { Siswa merasa senang } \\
\text { karena dengan adanya } \\
\text { kesiapan belajar dan } \\
\text { metode yang kreatif. }\end{array}$ & $\begin{array}{l}\text { Siswa merasa senang. } \\
\text { Dilihat dari cara siswa } \\
\text { menjawab salam, dan } \\
\text { raut wajah siswa yang } \\
\text { ceria. }\end{array}$ \\
\hline $\begin{array}{l}\text { Bagaimana kondisi/respon } \\
\text { siswa ketika guru } \\
\text { menyampaikan apersepsi? }\end{array}$ & \begin{tabular}{lrr} 
Siswa & \multicolumn{2}{r}{ menanggapi } \\
apersepsi guru dengan \\
contoh konkrit, karena \\
siswa mempersiapkan \\
materi secara mandir \\
sebelumnya.
\end{tabular} & $\begin{array}{l}\text { Siswa aktif menyebutkan } \\
\text { contoh konsep materi. }\end{array}$ \\
\hline $\begin{array}{l}\text { A. } \\
\text { agaimana interaksi } \\
\text { yang terjadi dalam } \\
\text { pembelajaran, siswa } \\
\text { dengan siswa, siswa } \\
\text { dengan guru? } \\
\begin{array}{l}\text { Deskripsikan pemicu } \\
\text { terjadinya interaksi. }\end{array}\end{array}$ & $\begin{array}{l}\text { Siswa dengan siswa: } \\
\text { Siswa aktif berdiskusi } \\
\text { dengan anggota kelompok } \\
\text { untuk menyelesaikan } \\
\text { masalah. } \\
\text { Siswa dengan guru: } \\
\text { Guru berkeliling } \\
\text { mengecek dan } \\
\text { memberikan arahan pada } \\
\text { setiap kelompok } \\
\text { Pemicu } \\
\text { interaksi. } \\
\text { Siswa mulai berinteraksi } \\
\text { ketika diberi masalah } \\
\text { dalam kelompoknya dan } \\
\text { karena guru aktif memebri } \\
\text { arahan serta mengecek } \\
\text { hasil diskusi kelompok. }\end{array}$ & $\begin{array}{l}\text { Siswa dengan siswa: } \\
\text { Siswa aktif berdiskusi } \\
\text { dalam kelompok. Karena } \\
\text { adanya penekanan tugas } \\
\text { dan tanggungjawab } \\
\text { setiap anggota kelompok } \\
\text { Siswa dengan guru: } \\
\text { Siswa mengajukan } \\
\text { pertanyaan kepada guru } \\
\text { saat tidak mengerti } \\
\text { masalah. } \\
\text { Pemicu terjadinya } \\
\text { interaksi. } \\
\text { Siswa mulai berdiskusi } \\
\text { dan bertanya ketika } \\
\text { diberi masalah berupa } \\
\text { LKS dan mencoba } \\
\text { menyelesaikannya } \\
\text { secara mandiri. Karena } \\
\text { adanya penekanan tugas } \\
\text { dan reward }\end{array}$ \\
\hline
\end{tabular}




\begin{tabular}{|c|c|c|c|}
\hline B. & $\begin{array}{l}\text { iswa mana yang tidak } \\
\text { bisa mengikuti } \\
\text { pembelajaran dengan } \\
\text { baik pada hari ini? } \\
\text { Berdasarkan bukti } \\
\text { konkrit }\end{array}$ & 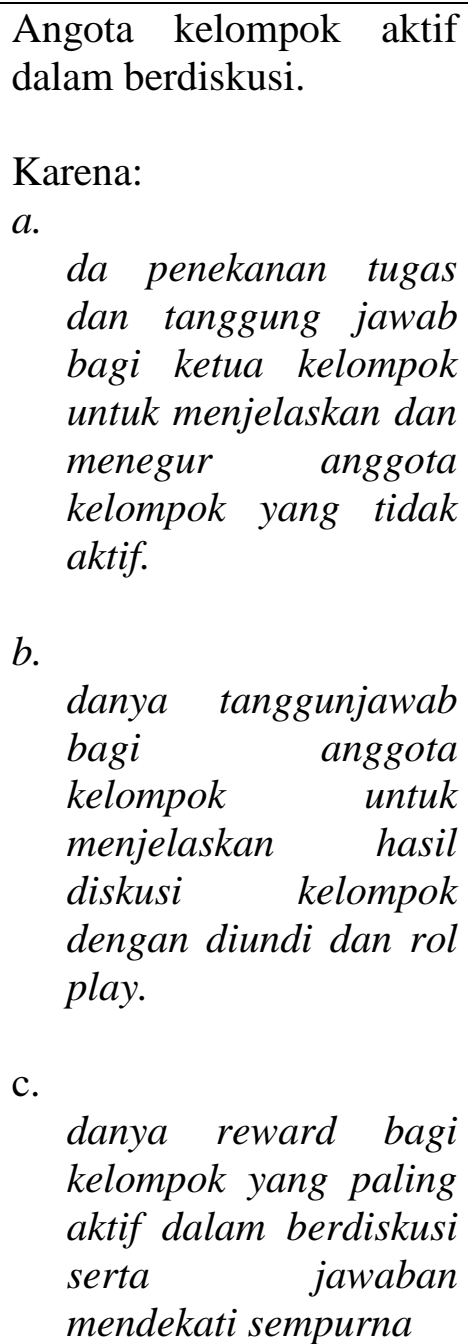 & 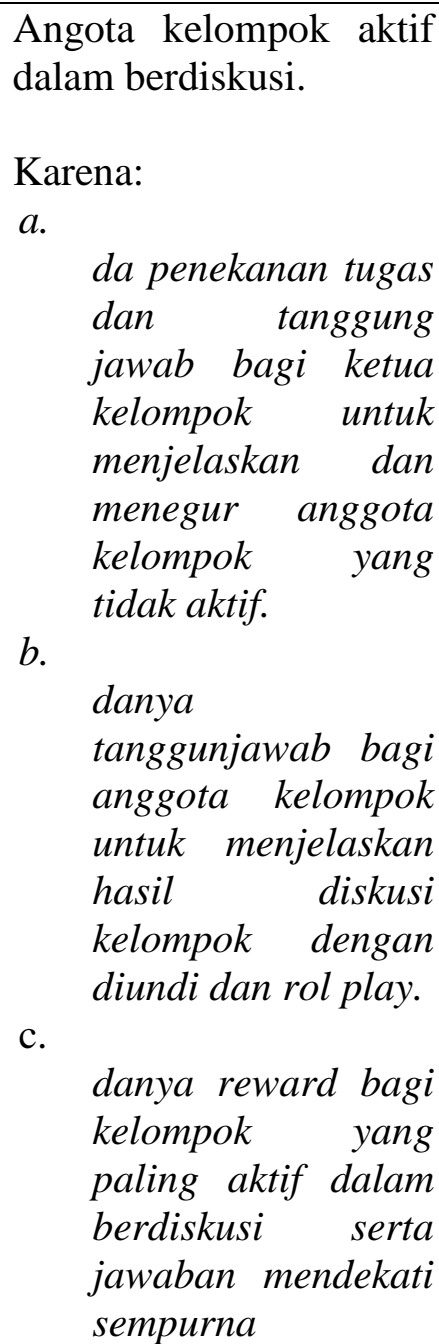 \\
\hline $\mathrm{C}$ & $\begin{array}{l}\text { eskripsikan hal-hal } \\
\text { unik yang terjadi pada } \\
\text { saat pembelajaran. }\end{array}$ & $\begin{array}{l}\text { Siswa merasa } \\
\text { pada saat dirinejut } \\
\text { mendapatkan giliran } \\
\text { untuk menjelaskan hasil } \\
\text { diskusi berdasarkan } \\
\text { undian dan rol play }\end{array}$ & $\begin{array}{l}\text { Siswa merasa senang } \\
\text { saat diberi ice breaking } \\
\text { setelah pikirannya mulai } \\
\text { lelah menyelesaikan } \\
\text { masalah, }\end{array}$ \\
\hline $\mathrm{A}$ & $\begin{array}{lr} & \\
\text { agaimana } & \text { siswa } \\
\text { terlibat dalam kegiatan } \\
\text { penutup (melakukan } \\
\text { refleksi, merangkum, } \\
\text { dll) }\end{array}$ & $\begin{array}{l}\text { Siswa mengajukan } \\
\text { pendapat mengenai materi } \\
\text { dan mampu menghargai } \\
\text { pendapat orang lain, siswa } \\
\text { membuat rangkuman } \\
\text { materi dengan baik }\end{array}$ & $\begin{array}{lr}\text { Siswa mencoba } \\
\text { mengungkapkan ide } \\
\text { mengenai pengetahuan } \\
\text { mereka sendiri tentang } \\
\text { materi, siswa mencatat } \\
\text { hal penting yang } \\
\text { diperoleh } \\
\text { pembelajaran. }\end{array}$ \\
\hline $\mathrm{B}$ & again & $\begin{array}{l}\text { Siswa meminta guru } \\
\text { untuk membuat masalah }\end{array}$ & $\begin{array}{l}\text { siswa merasa senang dan } \\
\text { lansung melakukan }\end{array}$ \\
\hline
\end{tabular}




\begin{tabular}{|l|l|l|}
\hline $\begin{array}{l}\text { ketika guru } \\
\text { menyampaikan tindak } \\
\text { lanjut pembelajaran.? }\end{array}$ & $\begin{array}{l}\text { yang lebih kontektual dan } \\
\text { problem solving open } \\
\text { ended }\end{array}$ & $\begin{array}{l}\text { tindak lanjut yang } \\
\text { diberikan guru. }\end{array}$ \\
\hline $\begin{array}{l}\text { Pelajaran berharga apa } \\
\text { yang dapat anda petik dari } \\
\text { pengamatan pembelajaran } \\
\text { hari ini? }\end{array}$ & $\begin{array}{l}\text { erorientasi pada tugas } \\
\text { dan tanggungjawab } \\
\text { enghargai pendapat } \\
\text { orang lain. }\end{array}$ & $\begin{array}{l}\text { erjasama kelompok. } \\
\text { aidiri dan penuh } \\
\text { tanggungjawab. }\end{array}$ \\
\hline
\end{tabular}

Berdasarkan tabel 3.1 tentang pengamatan aktivitas siswa dapat dijelaskan bahwa siswa sangat senang dengan adanya strategi pembelajaran inquiry. Hal ini terlihat pada saat guru model melakukan apersepsi siswa menanggapi dengan meberikan contoh konkrit karena siswa mempersiapkan materi dari rumah. Siswa juga mulai mengerti arah pembelajaran yang akan dicapai, mengerti tujuan materi. dan siswa mampu mengungkapkan idenya dalam pembelajaran

Interaksi antar siswa terjadi begitu aktif, baik interaksi dengan anggota kelompok maupun interaksi dengan kelompok lain. Interaksi dalam kelompok terjadi karena adanya penekanan tugas dan tangggjawab bagi setiap anggota kelompok dan tanggungjawab ketua kelompok untuk memberikan pemahaman bagi setiap anggota kelompoknya serta menegur anggota kelompok yang tidak aktif. Interaksi antar kelompok dipicu adanya keinginan dan semangat bagi setiap kelompok untuk menjadi yang terbaik dan mendapat reward dari guru. Dengan demikian reward sangat mendukung keaktifan siswa. Reward bisa dilakukan dengan penambahan poin, pemberihan hadiah, atau pemberian pujian. Interaksi antara siswa dengan guru juga dominan lebih aktif. Hal ini terjadi karena dalam proses pembelajaran guru berkeliling mengawasi, mengecek dan memberikan arahan kepada siswa.

Pembelajaran konvensional yang lebih menekankan peran guru (teacher centered) dan penghafalan siswa sebagai indikator keberhasilan tidak lagi menjadi bentuk pembelajaran yang tepat. Kebutuhan siswa dalam mengembangkan bakat dasar dan kecenderungan yang secara eksperiensif dimiliki siswa adalah modal utama dalam proses pendewasaan, pematangan dan pemantapan intelektual maupun 
emosional anak. Di samping itu, dengan memanfaatkan potensi dasar yang sudah dimiliki siswa, guru dapat lebih kreatif sehingga siswa dan guru akan menikmati pembelajaran sebagai sebuah kegiatan yang menyenangkan. Pembelajaran melalui inkuiri, dalam hal ini adalah salah satu model yang cukup membantu dalam mengembangkan bakat siswa. Sesuai situasi dan kondisi perkembangan emosi, moral dan intelektual siswa, inkuiri dapat didesain menjadi sebuah strategi pembelajaran yang menyenangkan. Untuk tingkat dasar, model inkuiri ringan dapat dijadikan salah satu strategi pengayaan dalam pembelajaran matematika agar menjadi sebuah mata pelajaran yang menarik dan menantang.

Strategi pembelajaran inkuiri dapat mengunakan media dengan upaya guru menyajikan sejumlah informasi tertentu melalui masalah, bahan bacaan, film, gambar atau yang lainnya. Kemudian guru mendorong siswa untuk menggambarkan atau memahami prinsip-prinsip yang terkandung dalam topik atau bahan yang disajikan melalui pertanyaan-pertanyaan. Demikian pula dengan bentuk inkuiri deduktif yang dikemukakan Schuman bahwa inkuiri dapat dimulai dengan cara yang sangat sederhana dalam membantu mengembangkan kreatifitas berpikir siswa. Akhinoglu (2008) menyatakan bahwa penerapan strategi inqury dapat meningkat kemampuan siswa terhadap ilmu pengetahuan dan teknologi kelas, peningkatan paling signifikan terjadi pada meningkatkan nilai dalam ujian selama dan setelah menyelesaikan masalah.

Hasil belajar siswa mengalami peningkatan karena siswa telah melakukan pembelajaran inkuiri dengan baik, karena pada setiap pertemuan aktivitas guru semakin meningkat dalam membimbing dan memberikan penguatan motivasi kepada siswa, membuat siswa lebih terpacu dalam proses pembelajaran. Dengan demikian proses pembelajaran berjalan baik, siswa akan aktif dalam belajar, mudah memahami materi, dan mudah menjawab soal-soal pada waktu tes. Upaya meningkatkan keterampilan proses juga dapat meningkatkan penguasaan konsep yang diukur dengan hasil belajar siswa. Nurhadi (2004) menyatakan hasil belajar merupakan perubahan tingkah laku siswa yang meliputi ranah kognitif, afektif dan psikomotor. Ketiga ranah tersebut berhubungan dengan kemampuan siswa untuk melakukan 
proses ilmiah sebagaimana cara ilmuan bekerja untuk membentuk pemahaman atau aspek kognitifnya terlebih dahulu. Dalam penelitian ini peningkatan hasil belajar tersebut juga dipengaruhi dari penerapan strategi pembelajaran inkuiri.

Langkah-langkah pembelajaran dengan metode pembelajaran inkuiri, antara lain:

1. Observasi atau pengamatan terhadap berbagai konsep dalam matematika.

2. Mengajukan pertanyaan tentang masalah yang dihadapi

3. Mengajukan dugaan atau kemungkinan jawaban.

4. Mengumpulkan data yang terkait dengan pertanyaan yang diajukan

5. Merumuskan kesimpulan-kesimpulan berdasarkan data.

\section{Kesimpulan}

Hasil penelitian ini menyatakan bahwa metode inquiry dapat merangsang pertanyaan, memberikan konsep dan prinsip penyelesaian yang terkait dengan masalah yang dihadapi siswa. sehingga metode inquiry menjadikan siswa lebih aktif dan kreatif serta mampu berpikir kritis dalam interaksi siswa maupun dalam menyelesaikan masalah dengan menggunakan kemampuannya secara mandiri.

\section{Rekomendasi Konstruktif Untuk Pembaikan Pembelajaran}

Sasaran Pembelajaran inkuiri adalah pembelajaran yang dapat dicapai dengan penerapan inkuiri adalah:

1. Sasaran kognitif

a) Memahami bidang khusus dari materi pelajaran

b) Mengembangkan keterampilan proses sains

c) Mengembangkan kemampuan bertanya, memecahkan masalah dan melakukan penelitian.

d) Menerapkan pengetahuan dalam situasi baru yang berbeda.

e) Mengevaluasi dan mensintesis informasi, ide dan masalah baru.

f) Memperkuat keterampilan berpikir kritis. 


\section{Sasaran afektif}

a) Mengembangkan minat terhadap pelajaran dan bidang ilmu

b) Memperoleh apresiasi untuk pertimbangan moral dan etika yang relevan dengan bidang ilmu tertentu.

c) Meningkatkan intelektual dan integritas.

d) Mendapatkan kemampuan untuk belajar dan menerapkan materi pengetahuan.

Strategi pembelajaran inkuiri merupakan strategi yang banyak dianjurkan, karena strtegi ini memiliki beberapa manfaat, diantaranya:

1. Metode inqury yang digunakan cukup efektif untuk pembelajaran siswa karena setiap siswa mempunyai tanggung jawab terhadap kelompoknya dan terlibat dalam proses diskusi antar anggota kelompok. Melalui diskusi dalam kelompok kecil cukup membantu siswa memahami materi.

2. Strategi pembelajaran inkuiri merupakan strategi yang menekankan pada pengembangan aspek kognitif, afektif, dan psikomotor secara seimbang, sehingga pembelajaran melalui strtegi ini dianggap lebih bermakna.

3. Strategi pembelajaran inkuiri memberikan ruang kepada siswa untuk belajar sesuai dengan gaya belajar mereka.

4. Strategi pembelajaran inkuiri merupakan strategi yang dianggap sesuai dengan perkembangan psikologi perkembangan modern yang menganggap belajar adalah proses perubahan tingkah laku berkat adanya pengalaman.

5. Strategi pembelajaran inkuiri dapat melayani kebutuhan siswa yang mempunyai kemampuan diatas rata-rata. Artinya, siswa yang memiliki kemampuan belajar bagus tidak akan terhambat oleh siswa yang lemah dalam belajar.

Selain mempunyai keunggulan, Strategi pembelajaran inkuiri juga mempunyai kelemahan, di antaranya:

1. Jika strategi pembelajaran inkuiri sebagai srategi pembelajaran, maka akan sulit mengontrol kegiatan dan keberhasilan sisiwa.

2. Strategi ini sulit dalam merencanakan pembelajaran oleh karena terbentuk dengan kebiasaan siswa dalam belajar. 
3. Memerlukan waktu yang lama dalam mengimplementasikanya, sehingga guru sulit menyesuaikanya dengan waktu yang telah ditentukan.

4. Selama kriteria keberhasilan belajar ditentukan oleh kemampuan siswa menguasai materi pelajaran, maka strategi pembelajaran inkuiri akan sulit diimplementasikan oleh setiap guru.

\section{DAFTAR RUJUKAN}

Akhinoglu. 2008. Assessment of the inquiry-based project Implementation process in science education Upon students' points of views, International Journal of Instruction. Vol.1, No.1 ISSN: 1694-609X.

Alberta. 2003. Alberta Learning. Learning and Teaching Resources Branch. Focus on inquiry: a teacher's guide to implementing inquiry-based learning.

Baxter, Juliet and William,. Steven. 2010. Social And Analytic Scaffolding In Middle School Mathematics. Managing The Dilemma Of Telling Volume. 13:7-26.

Bell, Allison R. 2011. The Nature Of Self-Regulation, Scaffolding, And Feedback In A Computerbased Developmental Mathematics Classroom, University of Maryland.

Bell, R., L. Smetana, and I. Binns. 2005. Simplifying inquiry instruction. The Science Teacher 72(7): 30-34

Bilgin, Ibrahim. 2009. The Effects of Guided Inquiry Instruction Incorporating a Cooperative Learning Approach on University Students' Achievement of Acid and Bases Concepts and Attitude Toward Guided Inquiry Instruction. Scientific Research and Essay Vol.4 (10), p: 1038-1046.

Burton, J. Mason, K. Stacy. 2010. Thinking Mathematically. England

Chambers, P. (2008). Teaching Mathematics Developing as a Reflective Secondary Teacher. London: SAGE Publications Ltd.

Creswell, Jonh W. 2009. Research Design: Quantitative, Qualitative, and Mixed MethodesApproach. SAGE Publication, Icn: Thaousand Oaks, California

Dell'Olio, J.M. \& Donk, T. (2007). Models of Teaching Connecting Student Learning With Standars.USA: SAGE Publications Ltd. 
Hannula, M.S., Maijala, M. \& Pehkonen, E. (2004). Development of Understanding Self-Confidence in Mathematics; Grades 5-8. Group for the Psychology of Mathematics Education.Vol. 3, pp 17-24.

Ju-ling Shih, dkk. 2010. An Inquiry-based Mobile Learning Approach to Enhancing Social Science Learning Effectiveness. Jurnal of Educational Technology \& Society. 13 (4), 50-62

Khan, Wali. 2012. Inquiry-Based Teaching in Mathematics Classroom in a Lower Secondary School Of Karachi, International Journal of Academic Research in Progressive Education and Development, Vol. 1, No. 2

Kubicek, P. John. 2005. Inquiry-based learning, the nature of science, andcomputer technology: New possibilities in science education. Canadian Journal of Learning and Technology. Vol 31(1). Page: 1-5.

Kuhlthau, C.C., Maniotes, L.K., \& Caspari, A.K. (2007). Guided Inquiry. USA: British Library Cataloguing.

Morgan, Candia. 2004. Mathematics Teaching School Subject 11-19. RoutledgeFalmler. US and Canada.

Munandar, Utami. 1995. Mengembangkan Kreativitas anak Berbakat. Jakarta: Gramedia.

Tall, David. 2002. Diagnosing Students' Difficulties in Learning Mathematics. International Journal of Mathematics Education in Science \& Technology. Volume. 12, No. 1, 7-15

Widhiartha, Putu Ashinta. 2008. Lesson Study: Sebuah Upaya Peningkatan Mutu Pendidik Pendidikan Nonformal. Surabaya: Balai Pengembangan pendidikan Nonformal dan informal (BPPNFI).

W. Gulo. 2008. Strategi Belajar-Mengajar. Jakarta. Grasindo. 